\title{
Methylphenidate Redistributes Vesicular Monoamine Transporter-2: Role of Dopamine Receptors
}

\author{
Verónica Sandoval, Evan L. Riddle, Glen R. Hanson, and Annette E. Fleckenstein \\ Department of Pharmacology and Toxicology, University of Utah, Salt Lake City, Utah 84112
}

It is well accepted that methylphenidate (MPD) inhibits dopamine (DA) transporter function. In addition to this effect, this study demonstrates that MPD increases vesicular $\left[{ }^{3} \mathrm{H}\right] \mathrm{DA}$ uptake and binding of the vesicular monoamine transporter-2 (VMAT-2) ligand dihydrotetrabenazine (DHTBZ) in a dose- and time-dependent manner in purified striatal vesicles prepared from treated rats. This change did not result from residual MPD introduced by the original in vivo treatment, because application of MPD in vitro $(\leq 1 \mu \mathrm{M})$ was without effect, and higher concentrations decreased vesicular $\left[{ }^{3} \mathrm{H}\right] \mathrm{DA}$ uptake. In addition, MPD treatment increased and decreased VMAT-2 immunoreactivity in striatal vesicle subcellular and plasmalemmal mem- brane fractions, respectively. The MPD-induced increase in both VMAT-2 immunoreactivity and DHTBZ binding was attenuated by pretreatment in vivo with either the $D A D_{1}$ receptor antagonist $\mathrm{SCH} 23390$ or the $\mathrm{DA}_{2}$ receptor antagonist eticlopride. Coadministration of these antagonists in vivo inhibited completely the MPD-induced increase in DHTBZ binding in the purified vesicular preparation. These observations suggest a role for DA in the MPD-induced redistribution of VMAT-2. The implications of this phenomenon will be discussed.

Key words: eticlopride; SCH23390; VMAT-2; $D_{1}$ receptor; $D_{2}$ receptor; vesicle redistribution
Methylphenidate (MPD) is one of the most commonly prescribed psychostimulants in the United States. Its primary clinical use is for the treatment of attention deficit hyperactivity disorder (Challman and Lipsky, 2000; Zuddas et al., 2000), which is estimated to affect 3-5\% of children in the United States (Pincus et al., 1995). There has been an increase in the illicit use of this stimulant presumably attributable to its pharmacological similarity to other drugs of abuse, such as cocaine. Specifically, MPD inhibits dopamine (DA) transporter function (Ritz et al., 1987; Pan et al., 1994; Izenwasser et al., 1999) and thereby increases extracellular DA levels (Hurd and Ungerstedt, 1989; Butcher et al., 1991).

The vesicular monoamine transporter-2 (VMAT-2) is responsible for the sequestration of cytoplasmic dopamine (Erickson et al., 1992) and is an important regulator of DA neurotransmission; still, no studies to date have investigated the effect of MPD on VMAT-2 function. Hence, the purpose of this study was to determine whether MPD affects VMAT-2 activity. Results reveal that a single administration of MPD rapidly and reversibly increases vesicular $\left[{ }^{3} \mathrm{H}\right] \mathrm{DA}$ uptake and binding of the VMAT-2 ligand $\left[{ }^{3} \mathrm{H}\right]$ dihydrotetrabenazine (DHTBZ). MPD treatment also increases VMAT-2 protein levels in a striatal vesicle subcellular preparation. These MPD-induced increases in vesicular $\left[{ }^{3} \mathrm{H}\right] \mathrm{DA}$ sequestration, $\left[{ }^{3} \mathrm{H}\right] \mathrm{DHTBZ}$ binding, and VMAT-2 protein levels are mediated by both $\mathrm{DA} \mathrm{D}_{1}$ and $\mathrm{D}_{2}$ receptor activation. These phenomena represent an MPD-induced redistribution of vesicles within nerve terminals that may, in turn, alter intraneuronal DA distribution. The implications of this phenomenon are discussed.

\footnotetext{
Received Dec. 18, 2001; revised July 3, 2002; accepted July 9, 2002.

This work was supported by National Institutes of Health Grants DA04222, DA00869, DA11389, and DA13367.

Correspondence should be addressed to Dr. Annette E. Fleckenstein, Department of Pharmacology and Toxicology, 30 South 2000 East, Room 201, University of Utah, Salt Lake City, UT 84112. E-mail: fleckenstein@hsc.utah.edu.

Copyright (C) 2002 Society for Neuroscience $0270-6474 / 02 / 228705-\bullet 15.00 / 0$
}

\section{MATERIALS AND METHODS}

Animals. Male Sprague Dawley rats (280-340 gm; Simonsen Laboratories, Gilroy, CA) were maintained under controlled lighting and temperature conditions, with food and water provided ad libitum. Rats were killed by decapitation using a guillotine. Striata $(40-50 \mathrm{mg}$ in weight per rat) were dissected and quickly placed in cold $0.32 \mathrm{~m}$ sucrose until tissue was processed (for details, see below). All procedures were conducted in accordance with National Institutes of Health Guidelines for the Care and Use of Laboratory Animals and approved by the University of Utah Institutional Animal Care and Use Committee.

Drugs and chemicals. ( \pm MDP hydrochloride was supplied by the National Institute on Drug Abuse (Bethesda, MD). 7,8-[ $\left.{ }^{3} \mathrm{H}\right] \mathrm{DA}$ (48 $\mathrm{Ci} / \mathrm{mmol}$ ) was purchased from Amersham Life Sciences (Arlington Heights, IL) and $\alpha-\left[2-{ }^{3} \mathrm{H}\right] \mathrm{DHTBZ}(20 \mathrm{Ci} / \mathrm{mmol})$ was purchased from American Radiolabeled Chemicals (St. Louis, MO). Tetrabenazine (TBZ) was kindly donated by Drs. Jeffrey Erickson (Louisiana State University Health Sciences Center, New Orleans, LA), Helene Varoqui (Louisiana State University Health Sciences Center) and Erik Floor (University of Kansas, Lawrence, KS). All drugs were administered at 1 $\mathrm{ml} / \mathrm{kg}$, as indicated in the figure legends. Doses were calculated as the respective free base, and drugs were dissolved in $0.9 \%$ saline.

Preparation of striatal synaptic vesicles. Synaptosomes were prepared from rat striatum as described previously (Fleckenstein et al., 1997). Synaptosomes were then resuspended and homogenized in cold distilled deionized water. Osmolarity was restored by the addition of HEPES and potassium tartrate (final concentration of 25 and $100 \mathrm{~mm}$, respectively, $\mathrm{pH}$ 7.5). Samples were centrifuged for $20 \mathrm{~min}$ at $20,000 \times g\left(4^{\circ} \mathrm{C}\right)$ to remove lysed synaptosomal membranes. $\mathrm{MgSO}_{4}(1 \mathrm{~mm}$, final concentration) was added to the supernatant, which was then centrifuged for 45 min at $100,000 \times g\left(4^{\circ} \mathrm{C}\right)$. The resulting vesicular pellet was resuspended in wash buffer (see below) at a concentration of $50 \mathrm{mg} / \mathrm{ml}$ (original wet weight of tissue).

Vesicular $\left[{ }^{3} \mathrm{H}\right] \mathrm{DA}$ uptake and $\left[{ }^{3} \mathrm{H}\right] \mathrm{DHTBZ}$ binding. Vesicular $\left[{ }^{3} \mathrm{H}\right] \mathrm{DA}$ uptake was performed by incubating $100 \mu \mathrm{l}(\sim 2.5 \mu \mathrm{g}$ of protein) of synaptic vesicle samples at $30^{\circ} \mathrm{C}$ for $3 \mathrm{~min}$ in assay buffer [final concentration (in mM): 25 HEPES, 100 potassium tartrate, 1.7 ascorbic acid, 0.05 EGTA, 0.1 EDTA, and 2 ATP- $\left.\mathrm{Mg}^{2+}, \mathrm{pH} 7.5\right)$ in the presence of $\left[{ }^{3} \mathrm{H}\right] \mathrm{DA}$ (30 nM final concentration, except in kinetic analyses wherein $0.8-10 \mu \mathrm{M}\left[{ }^{3} \mathrm{H}\right] \mathrm{DA}$ was used). The reaction was terminated by addition of $1 \mathrm{ml}$ of cold wash buffer (assay buffer containing $2 \mathrm{~mm} \mathrm{MgSO}_{4}$ substituted for the ATP- $\mathrm{Mg}^{2+}, \mathrm{pH}$ 7.5) and rapid filtration through Whatman GF/F filters soaked previously in $0.5 \%$ polyethylenimine. 
Filters were washed three times with cold wash buffer using a Brandel filtering manifold. Radioactivity trapped in filters was counted using a liquid scintillation counter. Nonspecific values were determined by measuring vesicular $\left[{ }^{3} \mathrm{H}\right] \mathrm{DA}$ uptake at $4^{\circ} \mathrm{C}$ in wash buffer.

Binding of $\left[{ }^{3} \mathrm{H}\right]$ DHTBZ was performed as described by Teng et al. (1998). Briefly, $200 \mu \mathrm{l}$ ( $\sim 6 \mu \mathrm{g}$ of protein) of the synaptic vesicle preparation was incubated in wash buffer in the presence of $\left[{ }^{3} \mathrm{H}\right]$ DHTBZ $(2$ $\mathrm{nM}$ final concentration, except in kinetic analyses wherein $0.25-500 \mathrm{nM}$ DHTBZ was used) for $10 \mathrm{~min}$ at $25^{\circ} \mathrm{C}$. The reaction was terminated by addition of $1 \mathrm{ml}$ of cold wash buffer and rapid filtration through Whatman GF/F filters soaked in $0.5 \%$ polyethylenimine. Filters were washed three times with ice-cold wash buffer. Radioactivity trapped in filters was counted using a liquid scintillation counter. Nonspecific binding was determined by coincubation with $20 \mu \mathrm{M}$ TBZ. All protein concentrations were determined by a Bio-Rad (Hercules, CA) protein assay.

Preparation of striatal subcellular fractions. Fresh striatal tissue was homogenized in ice-cold $0.32 \mathrm{M}$ sucrose and centrif uged $(800 \times g$ for 12 $\left.\min ; 4^{\circ} \mathrm{C}\right)$. The resulting supernatant $(\mathrm{S} 1)$ was then centrif uged $(22,000 \times$ $g$ for $20 \mathrm{~min} ; 4^{\circ} \mathrm{C}$ ), and the pellets [P2; whole synaptosomal fraction (plasmalemmal membrane plus vesicular subcellular fractions)] were resuspended in cold distilled deionized water at a concentration of 50 $\mathrm{mg} / \mathrm{ml}$ (original wet weight of tissue). Resuspended tissue was aliquoted into two test tubes. One aliquot was centrifuged $(22,000 \times g$ for $20 \mathrm{~min}$; $4^{\circ} \mathrm{C}$ ) to separate plasmalemmal membranes from the synaptic vesicleenriched fraction. The resulting supernatant (S3) contained the vesicular subcellular fraction of interest, and the pellets (P3; plasmalemmal membrane fraction) were resuspended in cold distilled deionized water.

Western blot analysis. VMAT-2 antibody was originally kindly donated by Dr. John Haycock (Louisiana State University, New Orleans, LA) and was subsequently purchased from Chemicon (Temecula, CA; AB1767). Binding of VMAT-2 antibody was performed using $60 \mu \mathrm{l}$ of whole synaptosomal, plasmalemmal membrane, or vesicle subcellular fractions. Samples were added to $20 \mu \mathrm{l}$ of loading buffer (final concentration, $2.25 \%$ SDS, $18 \%$ glycerol, $180 \mathrm{~mm}$ Tris base, $\mathrm{pH} 6.8,10 \% \beta$-mercaptoethanol, and bromophenol blue). Approximately $60 \mu \mathrm{g}$ of protein of the whole synaptosomal fraction, $40 \mu \mathrm{g}$ of protein of the plasmalemmal membrane fraction, or $20 \mu \mathrm{g}$ of protein of the vesicle subcellular fraction was loaded per well in a $10 \%$ SDS-polyacrylamide gel. After electrophoresis, samples were transferred to polyvinylidene difluoride hybridization transfer membrane (NEN, Boston, MA). All subsequent incubation steps were performed at room temperature while shaking. Each membrane was first blocked for $2 \mathrm{hr}$ in $100 \mathrm{ml}$ of Tris-buffered saline with Tween (TBST)

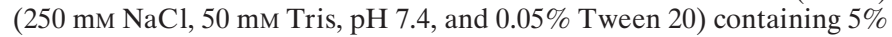
nonfat dry milk. Each membrane was then incubated with anti-VMAT-2 antibody (1:4000 dilution) in $13 \mathrm{ml}$ of TBST with 5\% milk for $1 \mathrm{hr}$ and then washed five times (two washes for $1 \mathrm{~min}$ each and three washes for 5 min each) in $70 \mathrm{ml}$ of TBST with $5 \%$ milk. The membranes then were incubated for $1 \mathrm{hr}$ with the goat $\mathrm{F}\left(\mathrm{ab}^{\prime}\right)_{2}$ anti-rabbit Ig antibody (Biosource International, Camarillo, CA) at a 1:2000 dilution in TBST with $5 \%$ milk. This secondary antibody had been affinity isolated, preabsorbed with human Ig, and conjugated with horseradish peroxidase. The membranes were then washed five times (two times for 1 min each and three times for $5 \mathrm{~min}$ each) with $70 \mathrm{ml}$ of TBST and then developed with the Renaissance Western Blot Chemiluminescence Reagent Plus (NEN) according to specifications of the manufacturer. Multiple exposures of blots were obtained to ensure development within the linear range of the film (Kodak Biomax MR; Eastman Kodak, Rochester, NY). Bands on blots were quantified by densitometry measuring net intensity (the sum of the background-subtracted pixel values in the band area) using Kodak 1D image-analysis software.

Data analysis. Statistical analyses among three or more groups were performed using an ANOVA, followed by a Fisher PLSD post hoc comparison. Analyses between two groups were conducted using a Student's $t$ test. Differences were considered significant if probability of error was $<5 \%$.

\section{RESULTS}

Results presented in Figure $1 A$ demonstrate that MPD increases vesicular $\left[{ }^{3} \mathrm{H}\right] \mathrm{DA}$ uptake after a single subcutaneous administration of $5,10,20$, or $40 \mathrm{mg} / \mathrm{kg}$ MPD, as assessed by measuring $\left[{ }^{3} \mathrm{H}\right] \mathrm{DA}$ uptake into purified striatal vesicles prepared from saline- or MPD-treated rats. This increase in vesicular $\left[{ }^{3} \mathrm{H}\right] \mathrm{DA}$ uptake was associated with an increase in binding of the VMAT-2 ligand $\left[{ }^{3} \mathrm{H}\right]$ DHTBZ (Fig. $1 B$ ). The increases in both

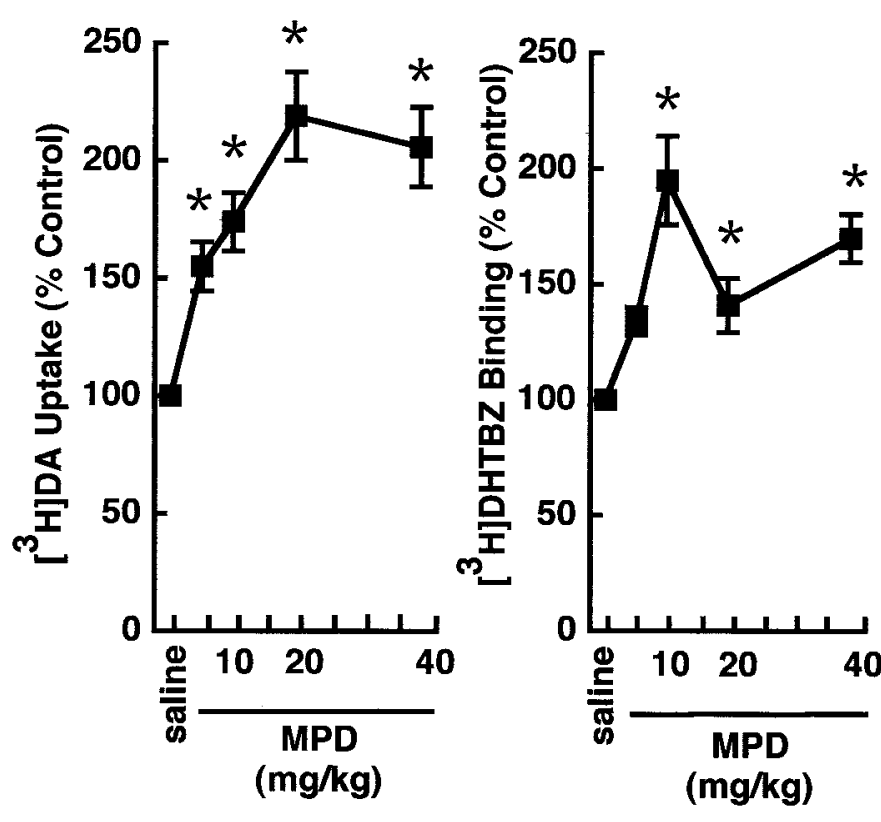

Figure 1. A single administration of MPD increases vesicular $\left[{ }^{3} \mathrm{H}\right] \mathrm{DA}$ uptake and $\left[{ }^{3} \mathrm{H}\right]$ DHTBZ binding. Rats received a single administration of MPD (5-40 mg/kg, s.c.) or saline vehicle $(1 \mathrm{ml} / \mathrm{kg}$, s.c.) and were killed $1 \mathrm{hr}$ later. Symbols represent the means, and vertical lines represent 1 SEM of determinations in six rats. Data are expressed as a percentage of the mean of control. Mean control values for vesicular $\left[{ }^{3} \mathrm{H}\right] \mathrm{DA}$ uptake and $\left[{ }^{3} \mathrm{H}\right]$ DHTBZ binding ranged from 81.4 to 167.3 and 1.2 to $2.3 \mathrm{fmol} / \mu \mathrm{g}$ protein, respectively. ${ }^{*} p \leq 0.05$, values for MPD-treated rats that are significantly different from saline-treated controls.

vesicular $\left[{ }^{3} \mathrm{H}\right] \mathrm{DA}$ uptake and $\left[{ }^{3} \mathrm{H}\right] \mathrm{DHTBZ}$ binding occur rapidly (i.e., within $30 \mathrm{~min}$ ) and reversibly (i.e., within $12 \mathrm{hr}$ after a 40 $\mathrm{mg} / \mathrm{kg}$ MPD administration) (Fig. 2). At these doses, MPD administration increased locomotor activity and rearing in the treated animals compared with controls (data not shown).

The MPD-induced increase in vesicular $\left[{ }^{3} \mathrm{H}\right] \mathrm{DA}$ uptake was associated with an increase in transporter $V_{\max }$ (for 3 min: $1584 \pm$ 129 and $2350 \pm 250 \mathrm{fmol} / \mu \mathrm{g}$ protein for saline- and MPD-treated rats, respectively; $p \leq 0.05)$ with little change in $K_{\mathrm{m}}(235 \pm 27$ and $230 \pm 10 \mathrm{~nm}$ for saline- and MPD-treated rats, respectively) (Fig. 3). MPD treatment also increased transporter $B_{\max }$ for the VMAT-2 ligand $\left[{ }^{3} \mathrm{H}\right] \mathrm{DHTBZ}$ (18.16 and $28.87 \mathrm{fmol} / \mu \mathrm{g}$ protein for saline- and MPD-treated rats, respectively) with little change in $K_{\mathrm{D}}$ (3.02 and $3.25 \mathrm{nM}$ for saline- and MPD-treated rats, respectively). This increase in vesicular $\left[{ }^{3} \mathrm{H}\right] \mathrm{DA}$ uptake did not result from residual MPD introduced by the original in vivo treatment, because direct application of MPD at concentrations of $1 \mathrm{nM}$ to $1 \mu \mathrm{M}$ was without effect, and higher concentrations of MPD decreased vesicular [ $\left.{ }^{3} \mathrm{H}\right] \mathrm{DA}$ uptake (i.e., the $\mathrm{IC}_{50}$ for MPD was $19.8 \pm 4.0 \mu \mathrm{M} ; n=3$ ).

To determine whether the MPD-induced increases in vesicular $\left[{ }^{3} \mathrm{H}\right] \mathrm{DA}$ uptake and $\left[{ }^{3} \mathrm{H}\right] \mathrm{DHTBZ}$ binding were associated with an increase in VMAT-2 protein levels, Western blot studies were conducted in three tissue fractions: vesicular subcellular fraction (i.e., synaptic vesicle enriched), plasmalemmal membrane fraction (i.e., membrane-bound vesicles), and whole synaptosomal fraction (i.e., vesicular subcellular plus plasmalemmal membrane fractions; for detailed description of fractionation, see Materials and Methods). In accordance with data presented in Figures 1 and 2, findings presented in Figure $4 A$ demonstrate that a single administration of MPD increases VMAT-2 immunoreactivity in 

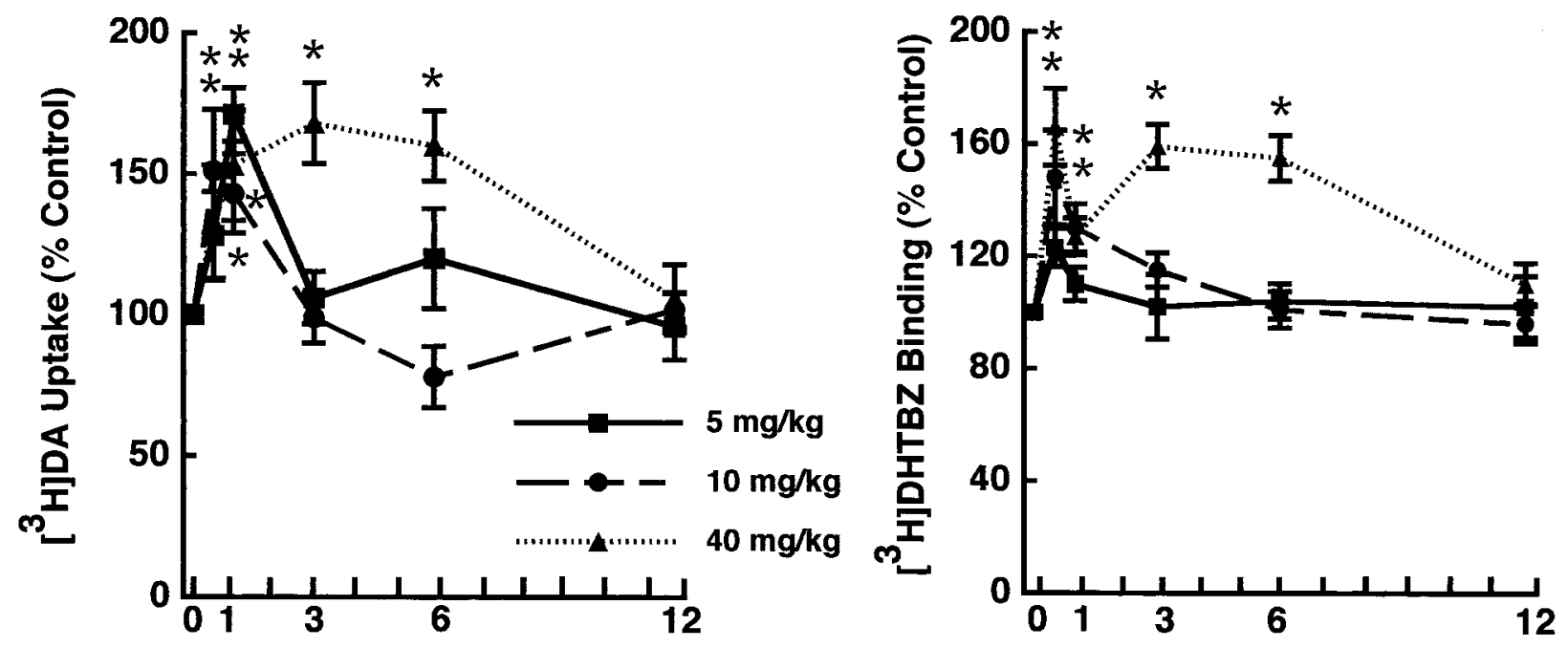

Hours After MPD Administration

Figure 2. A single administration of MPD rapidly and reversibly increases vesicular $\left[{ }^{3} \mathrm{H}\right] \mathrm{DA}$ uptake and $\left[{ }^{3} \mathrm{H}\right] \mathrm{DHTBZ}$ binding. Rats received a single administration of MPD $(5,10$, or $40 \mathrm{mg} / \mathrm{kg}$, s.c.) or saline vehicle $(1 \mathrm{ml} / \mathrm{kg}$, s.c.) and were killed $30 \mathrm{~min}$ to $12 \mathrm{hr}$ later. Symbols represent the means, and vertical lines represent 1 SEM of determinations in six rats. Data are expressed as a percentage of the mean of control. Mean control values for vesicular $\left[{ }^{3} \mathrm{H}\right] \mathrm{DA}$ uptake and $\left[{ }^{3} \mathrm{H}\right] \mathrm{DHTBZ}$ binding ranged from 135.2 to 226.3 and 4.6 to $7.1 \mathrm{fmol} / \mu \mathrm{g}$ protein, respectively. ${ }^{*} p \leq 0.05$, values for MPD-treated rats that are significantly different from saline-treated controls.

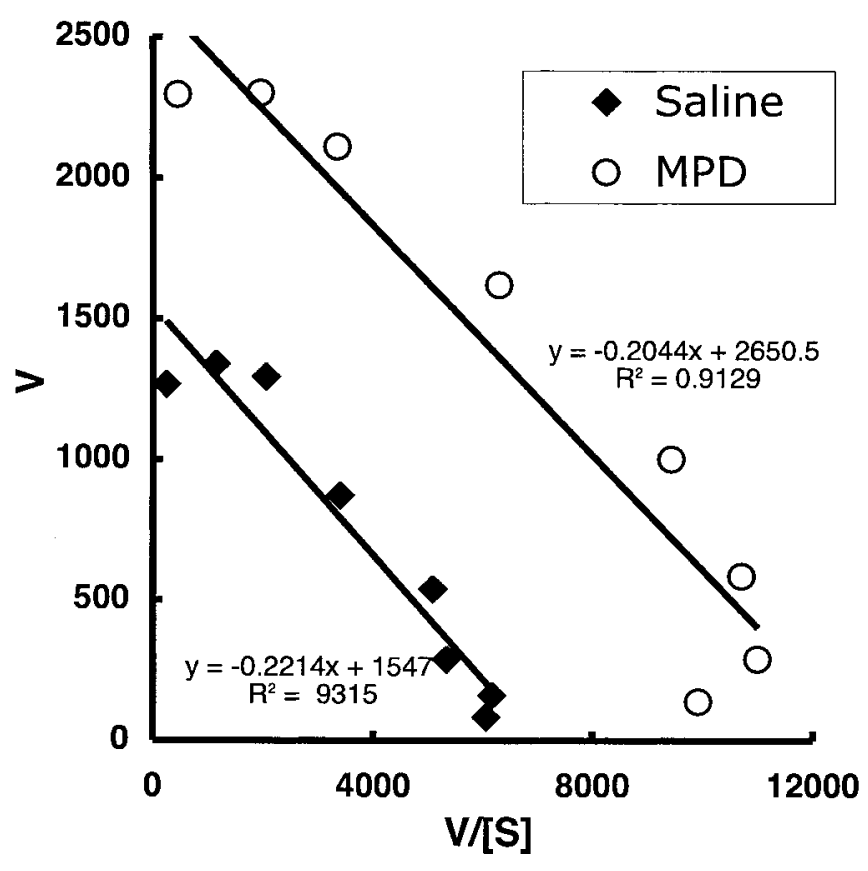

Figure 3. A single administration of MPD increases the $V_{\max }$ of vesicular $\left[{ }^{3} \mathrm{H}\right] \mathrm{DA}$ uptake. Rats received a single administration of MPD (40 $\mathrm{mg} / \mathrm{kg}$, s.c. $)$ or saline vehicle $(1 \mathrm{ml} / \mathrm{kg}$, s.c. $)$ and were $\mathrm{killed} 1 \mathrm{hr}$ later. The Eadie-Hofstee plot depicts data from one of four experiments, with samples in each run in duplicate. The mean $K_{\mathrm{m}}$ values were $235 \pm 27$ and $230 \pm 10 \mathrm{nM}$ for saline- and MPD-treated rats, respectively. The mean $V_{\max }$ values for all four experiments combined were $1584 \pm 129$ and $2350 \pm 250 \mathrm{fmol} / \mu \mathrm{g}$ protein for $3 \mathrm{~min}$ for saline- and MPD-treated rats, respectively; these values differed significantly $(p \leq 0.05)$.

the vesicular subcellular fraction. In addition, treatment with MPD decreased VMAT-2 immunoreactivity in the plasmalemmal membrane fraction (Fig. $4 B$ ), with no change in the whole synaptosomal fraction (Fig. $4 C$ ).
To determine whether DA receptor activation contributed to the MPD-induced increases in vesicular transport, $\left[{ }^{3} \mathrm{H}\right] \mathrm{DHTBZ}$ binding, and VMAT-2 protein levels, the $\mathrm{DA}_{1}$ receptor antagonist $\mathrm{SCH} 23390$ or the $\mathrm{DA} \mathrm{D}_{2}$ receptor antagonist eticlopride was administered before MPD treatment. Administration of SCH23390 attenuated the MPD-induced increases in vesicular $\left[{ }^{3} \mathrm{H}\right]$ DA uptake, $\left[{ }^{3} \mathrm{H}\right] \mathrm{DHTBZ}$ binding, and VMAT-2 immunoreactivity in the vesicular subcellular fraction (Fig. 5). Moreover, eticlopride pretreatment attenuated the increase in vesicular $\left[{ }^{3} \mathrm{H}\right] \mathrm{DA}$ uptake and completely prevented the MPD-induced increases in $\left[{ }^{3} \mathrm{H}\right] \mathrm{DHTBZ}$ binding and VMAT-2 immunoreactivity in the vesicular subcellular fraction (Fig. 5). Administration of either SCH23390 or eticlopride per se did not affect vesicular $\left[{ }^{3} \mathrm{H}\right] \mathrm{DA}$ uptake or $\left[{ }^{3} \mathrm{H}\right] \mathrm{DHTBZ}$ binding (Figs. 5, 6). Coadministration of these antagonists completely inhibited the increase in vesicular DA sequestration and $\left[{ }^{3} \mathrm{H}\right] \mathrm{DHTBZ}$ binding (Fig. 7).

\section{DISCUSSION}

The abuse of MPD has been increasing over the past years; for instance, a 1998 Indiana University survey found that nearly 7\% of the students surveyed reported having using MPD illicitly at least once, and $2.5 \%$ reported using it monthly or more frequently (United States Department of Justice, Drug Enforcement Administration, 2001). The abuse of MPD can be attributed to its pharmacological similarities to cocaine. In particular, the reinforcing effects of both stimulants are primarily attributable to their ability to inhibit the plasmalemmal DA transporter function. Despite that VMAT-2 has been shown to be an important DA regulator, no studies have been conducted on the effect of MPD on VMAT-2 function. Therefore, the present data demonstrate a novel finding that MPD increases vesicular $\left[{ }^{3} \mathrm{H}\right] \mathrm{DA}$ uptake and $\left[{ }^{3} \mathrm{H}\right] \mathrm{DHTBZ}$ binding rapidly and reversibly, as assessed in purified striatal vesicles prepared from treated rats. These findings are in accordance with previous observations that demonstrated that DA reuptake inhibitors such as cocaine, amfonelic acid, or GBR12935 increase vesicular $\left[{ }^{3} \mathrm{H}\right] \mathrm{DA}$ uptake and $\left[{ }^{3} \mathrm{H}\right] \mathrm{DHTBZ}$ bind- 
Vesicular Subcellular

Figure 4. A single administration of MPD redistributes VMAT-2 immunoreactivity. Rats received a single administration of MPD $(40 \mathrm{mg} / \mathrm{kg}$, s.c.) or saline vehicle $(1 \mathrm{ml} / \mathrm{kg}$, s.c.). All animals were killed $1 \mathrm{hr}$ after the MPD or saline injection. Bars represent the mean optic density, and error bars represent the SEM of determinations in six treated rats. Molecular mass standards (in kilodaltons) are shown to the left of the representative Western blot. * $p \leq 0.05$, values for MPD-treated rats that are significantly different from saline-treated controls. Fraction
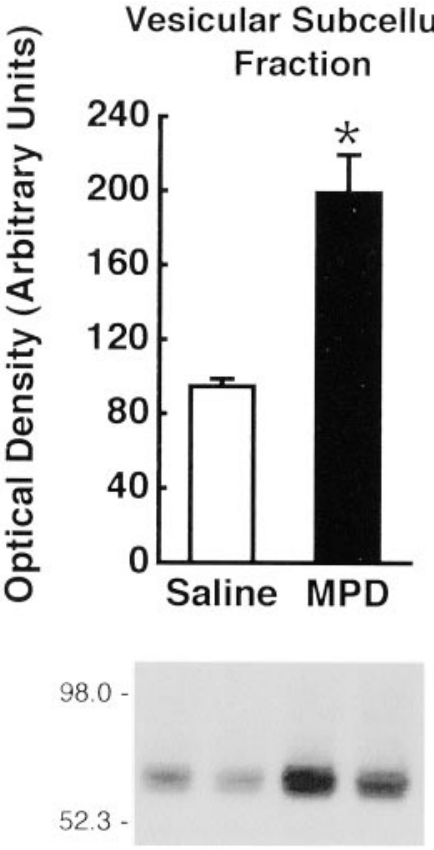

Plasmalemmal Membrane Fraction
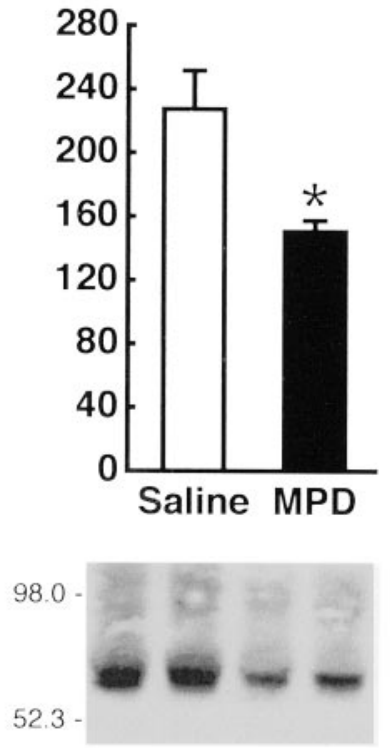

Whole Synaptosomal Fraction
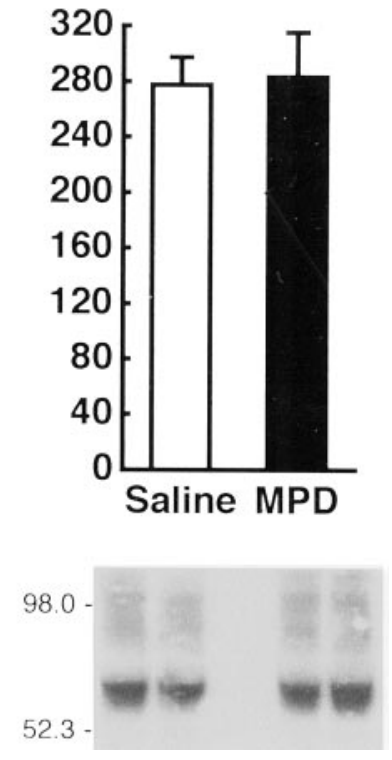

ing (Brown et al., 2001a). The MPD-induced effects, like the cocaine effects in VMAT-2 function (Brown et al., 2001), are attenuated by pretreatment with eticlopride. Pretreatment with SCH23390 attenuated the MPD-induced increases in vesicular $\left[{ }^{3} \mathrm{H}\right] \mathrm{DA}$ uptake and $\left[{ }^{3} \mathrm{H}\right] \mathrm{DHTBZ}$ binding, but it did not prevent the cocaine-induced increases in VMAT-2 activity (Brown et al., 2001). The coadministration of SCH 23390 and eticlopride completely inhibited the MPD-induced increases in VMAT-2 function. Hence, unlike the cocaine phenomenon, both $\mathrm{DA} \mathrm{D}_{1}$ and $\mathrm{D}_{2}$ receptor activation contribute to the increase in vesicular $\left[{ }^{3} \mathrm{H}\right] \mathrm{DA}$ uptake and $\left[{ }^{3} \mathrm{H}\right] \mathrm{DHTBZ}$ binding after MPD treatment.

Rapid effects on VMAT-2 have been reported previously after treatment with DA-releasing agents, such as methamphetamine (METH) and methylenedioxymethamphetamine (MDMA). For instance, vesicular $\left[{ }^{3} \mathrm{H}\right] \mathrm{DA}$ uptake and $\left[{ }^{3} \mathrm{H}\right] \mathrm{DHTBZ}$ binding are decreased $1 \mathrm{hr}$ after multiple METH or MDMA administrations (Brown et al., 2000; Hansen et al., 2002). These psychostimulants also acutely decrease plasmalemmal DA transporter function (Fleckenstein et al., 1997; Hansen et al., 2002). These data stand in contrast to our presently reported effect, specifically, that MPD increases (instead of decreases) vesicular DA uptake in our purified vesicular subcellular fraction. Hence, these data demonstrate that vesicular DA uptake can be bi-directionally regulated.

MPD not only increased vesicular $\left[{ }^{3} \mathrm{H}\right] \mathrm{DA}$ uptake and $\left[{ }^{3} \mathrm{H}\right]$ DHTBZ binding but also levels of the VMAT-2 immunoreactivity in the purified vesicle preparations. One explanation for this may be an increase in the synthesis of the VMAT-2 protein. This possibility is unlikely, because protein synthesis of transporter and receptor proteins typically requires days (Norman et al., 1987; Battaglia et al.,1988; Fleckenstein et al., 1996), a period much longer than the $30 \mathrm{~min}$ period at which increases in $\left[{ }^{3} \mathrm{H}\right] \mathrm{DA}$ uptake and $\left[{ }^{3} \mathrm{H}\right] \mathrm{DHTBZ}$ after MPD treatment were observed. A second possibility is an increase generation of functional vesicles. Ongoing studies are addressing this possibility. A third explanation for the MPD-induced increase in vesicular DA uptake, $\left[{ }^{3} \mathrm{H}\right] \mathrm{DHTBZ}$ binding, and VMAT-2 immunoreactivity in the vesicular-enriched subcellular fraction is that these increases are attributable to trafficking of vesicles within the dopaminergic neuron. For instance, MPD treatment may either prevent synaptic vesicle movement from a "cytoplasmic" pool (i.e., purified vesicular subcellular fraction) to the plasma membrane or, inversely, from the plasma membrane to the cytoplasm. Although the present findings cannot definitely discriminate between these possibilities, the data demonstrate that MPD treatment increases and decreases VMAT-2 immunoreactivity in the vesicular subcellular and plasmalemmal membrane fractions, respectively, suggesting that MPD redistributes VMAT-2 protein, and presumably synaptic vesicles, between a subcellular pool and the plasma membrane. In addition, the increase in VMAT-2 immunoreactivity may contribute to the increase in $V_{\max }$ of DA uptake after a single administration of MPD because VMAT-2 protein redistribution, and presumably that of synaptic vesicles, may underlie the increase in the quantity of purified vesicles in our preparation and, thereby, an augmentation in the $V_{\max }$ of the transporter. However, the possibility that some of the $V_{\max }$ increase might have resulted from an increase in rate (i.e., that the two phenomena are occurring simultaneously) cannot be entirely excluded. It is also relevant to note that, in accordance with results of the $\left[{ }^{3} \mathrm{H}\right] \mathrm{DHTBZ}$ binding studies, DA $\mathrm{D}_{1}$ and $\mathrm{D}_{2}$ receptor activation contribute to the MPD-induced increase in VMAT-2 immunoreactivity in the vesicular subcellular fraction because this increase was prevented by SCH23390 or eticlopride pretreatment (Figs. 5, 6). The mechanism(s) underlying this phenomenon remains to be determined.

One possible mechanism whereby MPD treatment causes a redistribution of VMAT-2 protein and presumably synaptic vesicular trafficking may involve presynaptic and/or postsynaptic DA $D_{2}$ receptors. The precise anatomical location of these receptors is unknown, although it is likely that these are ones associated with nigrostriatal regulation. It has been demonstrated that vesicular $\left[{ }^{3} \mathrm{H}\right] \mathrm{DA}$ uptake is increased by administration of the $\mathrm{DA} \mathrm{D}_{2}$ receptor agonist quinpirole (Brown et al., 2001b). Interestingly, it has been demonstrated that $\mathrm{DA}_{2}$ receptors are negatively coupled to cAMP (Stoof and Kebabian, 1981; Vallar and Meldolesi, 1989) and that a decrease in cAMP leads to a decline in protein kinase A (PKA) activation (Beavo et al., 1974). 

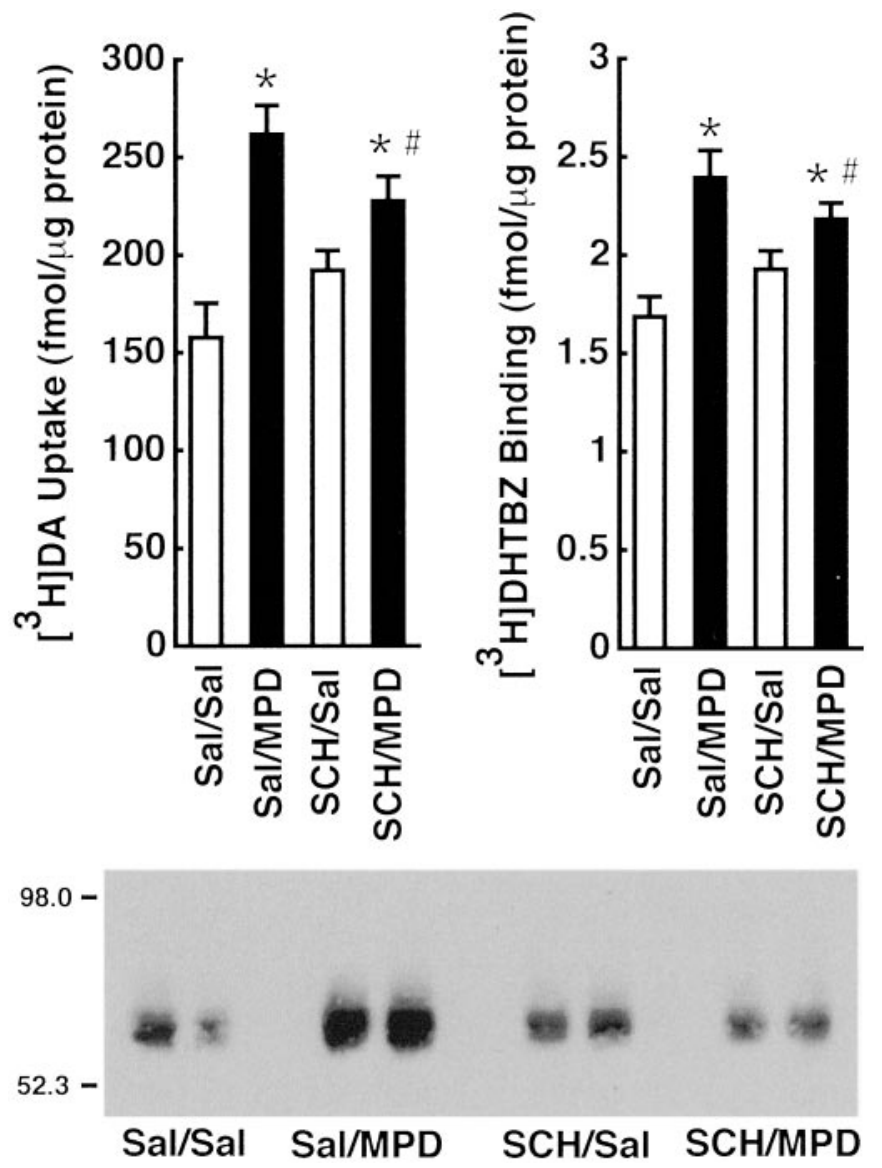

Figure 5. A DA $\mathrm{D}_{1}$ receptor antagonist, $\mathrm{SCH} 23390$, attenuates the MPD-induced increases in vesicular $\left[{ }^{3} \mathrm{H}\right] \mathrm{DA}$ uptake, $\left[{ }^{3} \mathrm{H}\right] \mathrm{DHTBZ}$ binding, and VMAT-2 immunoreactivity. Rats received a single administration of SCH23390 (SCH; $0.5 \mathrm{mg} / \mathrm{kg}$, i.p.) or saline vehicle $(\mathrm{Sal} ; 1 \mathrm{ml} / \mathrm{kg}$, i.p.) $15 \mathrm{~min}$ before a single administration of either MPD $(40 \mathrm{mg} / \mathrm{kg}$, s.c.) or saline vehicle $(1 \mathrm{ml} / \mathrm{kg}$, s.c.). All animals were killed $1 \mathrm{hr}$ after the last injection. Bars represent the mean vesicular $\left[{ }^{3} \mathrm{H}\right] \mathrm{DA}$ uptake and $\left[{ }^{3} \mathrm{H}\right] \mathrm{DHTBZ}$ binding, and error bars represent the SEM of determinations in six treated rats. Molecular mass standards (in kilodaltons) are shown to the left of the representative Western blot. * $p \leq 0.05$, values for MPD-treated rats that are significantly different from saline-treated controls; $\# p \leq 0.05$, values for SCH23390/MPD-treated animals that are significantly different from MPD-treated animals.

Synaptic vesicles are tethered to cytoskeleton fibers via synapsin, and synapsin is phosphorylated by protein PKA or calmodulin kinase (Turner et al., 1999). Once synapsin becomes phosphorylated, vesicles traffic from the cytoplasm to the plasma membrane (Turner et al., 1999). Consequently, a DA $\mathrm{D}_{2}$ receptor-mediated decrease in PKA activation could cause less synapsin to be phosphorylated and thereby increase the amount of synaptic vesicles tethered to cytoskeletal filaments. This increase in tethered vesicles may underlie the increase in the quantity of purified vesicles in our preparation. This hypothesis does not eliminate the possibility of postsynaptic $\mathrm{D}_{2}$ receptor involvement, because DA depletions caused by $\alpha \mathrm{MPT}$ treatment can potentially cause decreases in extracellular DA concentrations, and yet $\alpha \mathrm{MPT}$ treatment increases vesicular DA uptake (Brown et al., 2001a). Additional investigation regarding the interaction between DA $\mathrm{D}_{2}$ receptors and synaptic vesicles is necessary.

The finding that postsynaptic $\mathrm{DA}_{1}$ receptors contribute to the MPD-induced increase in vesicular $\left[{ }^{3} \mathrm{H}\right] \mathrm{DA}$ uptake, $\left[{ }^{3} \mathrm{H}\right] \mathrm{DHTBZ}$
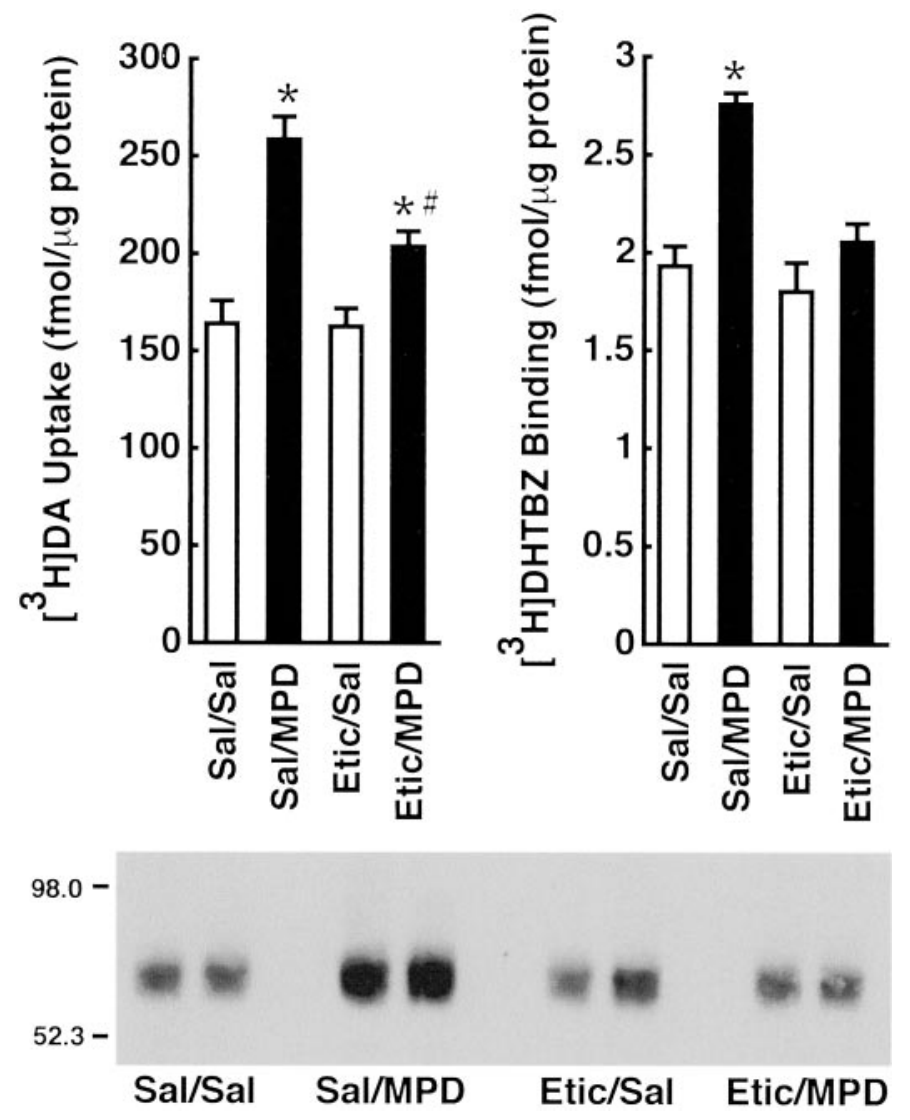

Figure 6. $\mathrm{A} \mathrm{DA}_{2}$ receptor antagonist, eticlopride, attenuates the MPD-induced increases in vesicular $\left[{ }^{3} \mathrm{H}\right] \mathrm{DA}$ uptake, $\left[{ }^{3} \mathrm{H}\right] \mathrm{DHTBZ}$ binding, and VMAT-2 immunoreactivity. Rats received a single administration of eticlopride (Etic; $0.5 \mathrm{mg} / \mathrm{kg}$, i.p.) or saline vehicle $(\mathrm{Sal} ; 1 \mathrm{ml} / \mathrm{kg}$, i.p.) $15 \mathrm{~min}$ before a single administration of either MPD ( $40 \mathrm{mg} / \mathrm{kg}$, s.c.) or saline vehicle $(1 \mathrm{ml} / \mathrm{kg}$, s.c.). All animals were killed $1 \mathrm{hr}$ after the last injection. Bars represent the mean vesicular $\left[{ }^{3} \mathrm{H}\right] \mathrm{DA}$ uptake and $\left[{ }^{3} \mathrm{H}\right] \mathrm{DHTBZ}$ binding, and error bars represent the SEM of determinations in six treated rats. Molecular mass standards (in kilodaltons) are shown to the left of the representative Western blot. * $p \leq 0.05$, values for MPD-treated rats that are significantly different from saline-treated controls; $\# p \leq 0.05$, values for eticlopride/MPD-treated animals that are significantly different from MPD-treated animals.

binding, and VMAT-2 immunoreactivity was unexpected because previous findings by Brown et al. (2001b) demonstrated that administration of a DA $D_{1}$ receptor agonist, SKF81297, does not increase vesicular $\left[{ }^{3} \mathrm{H}\right] \mathrm{DA}$ uptake or $\left[{ }^{3} \mathrm{H}\right] \mathrm{DHTBZ}$ binding. A possible explanation for the MPD-induced changes may be that $\mathrm{DA} \mathrm{D}_{1}$ receptor activation needs to occur concurrently with $\mathrm{DA} \mathrm{D}_{2}$ receptor activation for MPD to exert its effects. Future studies are necessary to elucidate any interactions among DA receptors in altering vesicular trafficking.

In conclusion, the data presented demonstrate that a single administration of MPD rapidly and reversibly increases vesicular $\left[{ }^{3} \mathrm{H}\right] \mathrm{DA}$ uptake and $\left[{ }^{3} \mathrm{H}\right] \mathrm{DHTBZ}$ binding by activating both DA $\mathrm{D}_{1}$ and $\mathrm{D}_{2}$ receptors. This phenomenon may result from an MPD-induced redistribution of vesicles within nerve terminals. Pharmacologically altering vesicular trafficking may have important implications beyond explaining differences between the longterm effects of MPD. For instance, autoxidation of cytoplasmic DA has been implicated in the development of Parkinson's disease (Cohen 1990; Fahn and Cohen, 1992; Jenner, 1998; Adams et al., 2001). Accordingly, pharmacological manipulations such as 


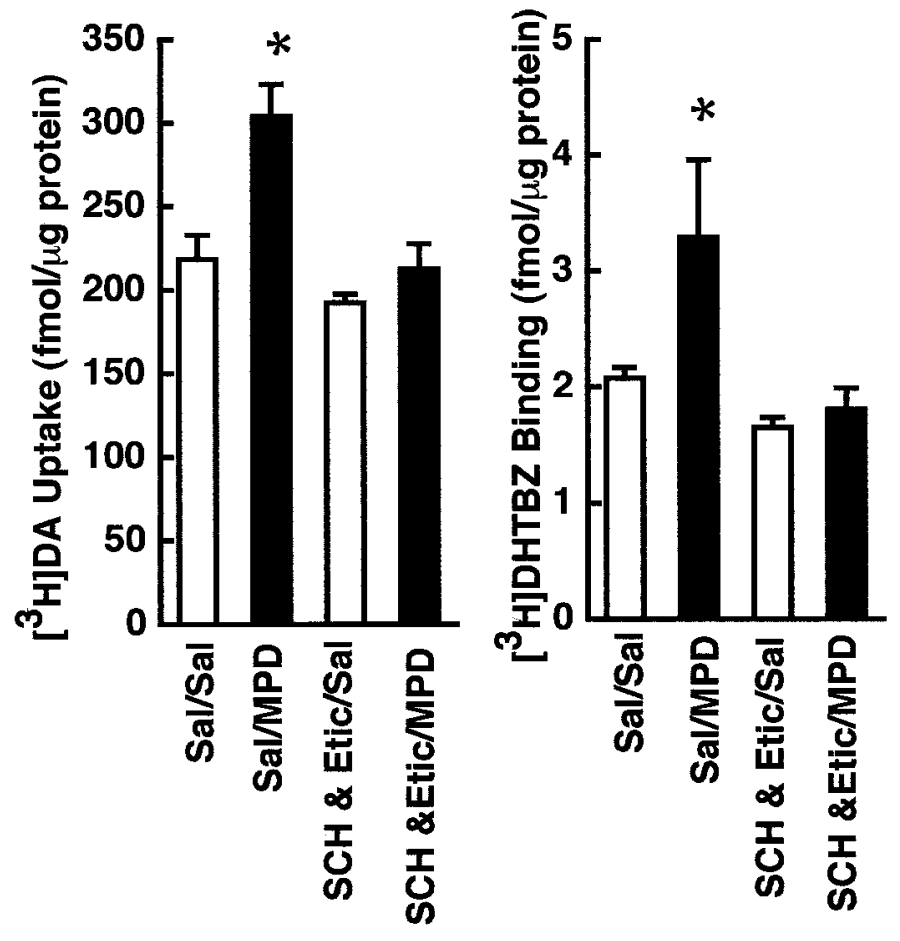

Figure 7. Coadministration of SCH 23390 and eticlopride blocks the MPD-induced increases in vesicular $\left[{ }^{3} \mathrm{H}\right] \mathrm{DA}$ uptake and $\left[{ }^{3} \mathrm{H}\right] \mathrm{DHTBZ}$ binding. Rats received a single administration of SCH23390 and eticlopride (SCH \& Etic; $0.5 \mathrm{mg} / \mathrm{kg}$, i.p.) or saline vehicle ( $\mathrm{Sal} ; 1 \mathrm{ml} / \mathrm{kg}$, i.p.) 15 min before a single administration of either MPD $(40 \mathrm{mg} / \mathrm{kg}$, s.c.) or saline vehicle $(1 \mathrm{ml} / \mathrm{kg}$, s.c.). All animals were killed $1 \mathrm{hr}$ after the last injection. Bars represent the mean vesicular $\left[{ }^{3} \mathrm{H}\right] \mathrm{DA}$ uptake and $\left[{ }^{3} \mathrm{H}\right]$ DHTBZ binding, and error bars represent the SEM of determinations in six treated rats. ${ }^{*} p \leq 0.05$, values for MPD-treated rats that are significantly different from saline-treated controls.

MPD treatment that increase vesicular uptake may be useful in slowing the progression of neurodegeneration by stimulating vesicular removal of DA from potentially unstable cytoplasmic DA pools. Precedence for a neuroprotective sequestering function for VMAT-2 in a neurotoxicity model was suggested previously by the demonstration that VMAT-2 sequesters and thereby protects against the DA neuronal damage caused by the neurotoxin $N$-methyl-4-phenylpyridinium (Liu et al., 1992; Staal et al., 2000). Interestingly, Falkenburger et al. (2001) demonstrated recently that administration of GBR-12935 [a DA transporter blocker that, like MPD, increases vesicular $\left[{ }^{3} \mathrm{H}\right] \mathrm{DA}$ uptake (Brown et al., 2001a)] abolishes the dendritic release of DA that leads to dendrodendritic autoinhibition. Authors in this study concluded that DA transporter inhibitors may benefit patients in the early stages of Parkinson's disease. Whether a pharmacological enhancement of VMAT-2 function would have clinical relevance remains to be established. However, data presented here suggest that vesicular DA uptake can be regulated and may be a valuable target for treatment of disorders involving disruption of normal DA disposition.

\section{REFERENCES}

Adams Jr JD, Chang ML, Klaidman L (2001) Parkinson's diseaseredox mechanisms. Curr Med Chem 8:809-814.

Battaglia G, Norman AB, Creese I (1988) Age-related differential recovery rates of rat striatal D-1 dopamine receptors following irreversible inactivation. Eur J Pharmacol 145:281-290.

Beavo JA, Bechtel PJ, Krebs EG (1974) Activation of protein kinase by physiological concentrations of cyclic AMP. Proc Natl Acad Sci USA 71:3580-3583.

Brown JM, Hanson GR, Fleckenstein AE (2000) Methamphetamine rapidly decreases vesicular dopamine uptake. J Neurochem 74:22212223.

Brown JM, Hanson GR, Fleckenstein AE (2001a) Regulation of the vesicular monoamine transporter-2: a novel mechanism for cocaine and other psychostimulants. J Pharmacol Exp Ther 296:762-767.

Brown JM, Hanson GR, Fleckenstein AE (2001b) Cocaine-induced increases in vesicular dopamine uptake: role of dopamine receptors. J Pharmacol Exp Ther 298:1150-1153.

Butcher SP, Liptrot J, Aburthnott GW (1991) Characterisation of methylphenidate and nomifensine induced dopamine release in rat striatum using in vivo brain microdialysis. Neurosci Lett 122:245-248.

Challman TD, Lipsky JJ (2000) Methylphenidate: its pharmacology and uses. Mayo Clin Proc 75:711-721.

Cohen G (1990) Monoamine oxidase and oxidative stress at dopaminergic synapses. J Neural Transm Suppl 32:229-238.

Erickson JD, Eiden LE, Hoffman BJ (1992) Expression cloning of a reserpine-sensitive vesicular monoamine transporter. Proc Natl Acad Sci USA 89:10993-10997.

Fahn S, Cohen G (1992) The oxidant stress hypothesis in Parkinson's disease: evidence supporting it. Ann Neurol 32:804-812.

Falkenburger BH, Barstow KL, Mintz IM (2001) Dendrodendritic inhibition through reversal of dopamine transport. Science 293:2465-2470.

Fleckenstein AE, Pogun S, Carroll FI, Kuhar MJ (1996) Recovery of dopamine transporter binding and function after intrastriatal administration of the irreversible inhibitor RTI-76 [3-beta-(3p-chlorophenyl) tropan-2 beta-carboxylic acid $\mathrm{p}$ isothiocyanatophenylethyl ester hydrochloride]. J Pharmacol Exp Ther 279:200-206.

Fleckenstein AE, Metzger RR, Wilkins DG, Gibb JW, Hanson GR (1997) Rapid and reversible effects of methamphetamine on dopamine transporters. J Pharmacol Exp Ther 282:834-838.

Hansen JP, Riddle EL, Sandoval V, Brown JM, Gibb JW, Hanson GR, Fleckenstein AE (2002) Methylenedioxymethamphetamine decreases plasmalemmal and vesicular dopamine transport: mechanisms and implications for neurotoxicity. J Pharmacol Exp Ther 300:1093-1100.

Hurd YL, Ungerstedt U (1989) In vivo neurochemical profile of dopamine uptake inhibitors and releasers in rat caudate-putamen. Eur J Pharmacol 166:251-260.

Izenwasser S, Coy AE, Ladenheim B, Loeloff RJ, Cadet JL, French D (1999) Chronic methylphenidate alters locomotor activity and dopamine transporters differently from cocaine. Eur J Pharmacol 373:187-193.

Jenner P (1998) Oxidative mechanisms in nigral cell death in Parkinson's disease. Mov Disord 13 [Suppl 1]:24-34.

Liu Y, Peter D, Roghani A, Schuldiner S, Prive GG, Eisenberg D, Brecha N, Edwards RH (1992) A cDNA that suppresses MPP+ toxicity encodes a vesicular amine transporter. Cell 70:539-551.

Norman AB, Battaglia G, Creese I (1987) Differential recovery rates of rat $D_{2}$ dopamine receptors as a function of aging and chronic reserpine treatment following irreversible modification: a key to receptor regulatory mechanisms. J Neurosci 7:1484-1491.

Pan D, Gatley SJ, Dewey SL, Chen R, Alexoff DA, Ding Y, Fowler JS (1994) Binding of bromine-substituted analogs of methylphenidate to monoamine transporters. Eur J Pharmacol 264:177-182.

Pincus HA, Wise T, First MB (1995) Diagnostic and statistical manual of mental disorders, primary care version, Ed 4, pp 182-184. Washington, DC: American Psychiatric Association.

Ritz MC, Lamb RJ, Goldberg SR, Kuhar MJ (1987) Cocaine receptors on dopamine transporters are related to self-administration of cocaine. Science 237:1219-1223.

Staal RG, Hogan KA, Liang CL, German DC, Sonsalla PK (2000) In vitro studies of striatal vesicles containing the vesicular monoamine transporter (VMAT2): rat versus mouse differences in sequestration of 1-methyl-4-phenylpyridinium. J Pharmacol Exp Ther 293:329-335.

Stoof JC, Kebabian JW (1981) Opposing roles for D-1 and D-2 dopamine receptors in efflux of cyclic AMP from rat neostriatum. Nature 294:366-368.

Teng L, Crooks PA, Dwoskin LP (1998) Lobeline displaces $\left[{ }^{3} \mathrm{H}\right]$ dihydrotetrabenazine binding and releases $\left[{ }^{3} \mathrm{H}\right]$ dopamine from rat striatal synaptic vesicles: comparison with d-amphetamine. J Neurochem $71: 258-265$.

Turner KM, Burgoyne RD, Morgan A (1999) Protein phosphorylation and the regulation of synaptic membrane traffic. Trends Neurosci 22:459-464.

United States Department of Justice, Drug Enforcement Administration, Diversion Enforcement Administration (2001) Stimulant abuse by school age children: a guide for school officials. http//www.deadiversion.usdoj. gov:80/pubs/brochures/stimulant/stimulant_abuse.htm.

Vallar L, Meldolesi J (1989) Mechanisms of signal transduction at the dopamine $\mathrm{D}_{2}$ receptor. Trends Pharmacol Sci 10:74-77.

Zuddas A, Ancilletta B, Muglia P, Cianchetti C (2000) Attention-deficit/hyperactivity disorder: a neuropsychiatric disorder with childhood onset. Eur J Paediatr Neurol 4:53-62. 